\title{
On Credit of Group-Buying Websites and the Countermeasures
}

\author{
Xiaojun Wang; Jing Kang ${ }^{*}$, Min Zhou \\ School of Economic and management \\ Changchun University of Science and Technology \\ Changchun, China \\ e-mail: kangjing@cust.edu.cn
}

\begin{abstract}
As a new way to shop, group-buying is popular among younger consumers with its cheap, new forms and convenience. However group buying not only brings benefits, it also brings many problems, such as poor credit, after-sales service problem and low barriers to entry, which plagued the website development. It is time to solve credit issues of bulk purchasing in website. This paper aims to group-buying website, analyzing the credit problem. Finally, we propose strategy, including credit evaluation, after-sales service, laws and regulations, etc.
\end{abstract}

\section{Keywords-Bulk Purchasing; Credit; Website; Strategy}

\section{INTRODUCTION}

In recent years, the group-buying website application has developed rapidly. According to the survey data of Commerce Research Center, during June 2011, the online buyers have reached 4220 , and the utilization rate increased from $4.1 \%$ to $8.7 \%$, with the growth rate of $125.0 \%$ [1]. The form of online shopping is developing quickly due to its economic characteristics; for instance, more and more consumers prefer it. But it revealed a number of contradictions in the process of rapid development, such as the illegal business fraud, serious credit problems, and consumer rights. These problems have become the serious impediment to the healthy development of the online groupbuying industry, which urgently need to be solved and improved.

\section{OVERVIEW OF SHOPPING ONLINE}

C2B e-commerce is a kind of e-business models, i.e. Consumer-to-business (customer to business). It is firstly popped up by the United States, but in China it has some simple prototype. The core of the $\mathrm{C} 2 \mathrm{~B}$ model is to aggregate the huge number of users dispersed, forming a powerful buying group, in order to change the weak position of oneto-one bid in the $\mathrm{B} 2 \mathrm{C}$ model. So consumers enjoy paying the price of the big wholesalers for member commodity interests.

$\mathrm{C} 2 \mathrm{~B}$, a form of e-business models (consumer to business), is a new e-commerce model. Group purchasing, also known as group purchase, refer to consumers who know or do not know each other come together, and increase the ability to negotiate with the business in order to achieve the best price, which is the way to shop. According to the principle of small profits, businesses can give the buyer discount below the retail price and the quality services which cannot be achieved by single purchase. It is teamwork to purchase certain goods or services [2].

According to the organizers, there are three modes of online group buying [3].

\section{A. Purchase by Consumers sponaneously}

The consumer groups or individuals who have the same intention to buy spontaneously organize themselves to buy from manufacturers in bulk, which is called spontaneous buying online. It is the initial form of online group buying. Usually consumer groups or individuals use online tools such as BBS, newsgroups to establish a buying theme, so as to attract more consumers to join to form the groups of a certain size and product manufacturers bargaining, and ultimately to lower prices to obtain the desired products or services.

Due to the limitations of the sponsors, members who join and exit the online group-buying groups are arbitrary, so it is difficult to protect the goals of the purchase.

\section{B. Buying mode launched by manufacturers}

Among buying mode in network marketing, the manufacturers obtain the initiative of online group buying, as the initiator of the organization of online shopping for their own products. They put online shopping into the marketing system to form a network-marketing mode.

\section{Buying mode by Third-party network platform}

Currently, the prevalent buying mode is online thirdparty network platform, which is the main point of this paper. This mode means the third party, except sellers and buyers, organizes group buying. They form an online shopping platform to issue relevant group buying products information, including product description, original price, time limit, discount and so on. When the purchase quantity reaches the standard, group buying will be done, otherwise it fails. The consumers will send the order information to the group buyers by the website. The consumers need to consume at the named sellers or the sellers can deliver the goods to the buyers. At the same time, the group buying website is responsible for monitoring the sellers' business credit, and accepts consumers' real-time complains. This mode has the characteristics of normative procedures, professional goods or services. Group buying website has become the main mode of online group buying. According to the goods and services provided by group buying website, it can be divided into three forms: life service information, specific products and navigation. 
1) Buying mode of life service information: These kinds of websites mainly issue all sorts of life service information, such as catering, massage, entertainment. One preferential service is displayed on website everyday, in order to attract more consumers to experience, such as "hand-in-hand", "24 volumes".

2) Buying mode of physical commodities: Buying mode of physical commodity is the range of market-oriented in regional market. It can also be a national market, because the physical commodity mode is common in the online trading platform launched by networks, such as cosmetics limited sale site, "superior products".

3) Buying mode of Navigation: Buying mode of Navigation builds various types of website of buying information. Buying information makes users navigate their own interest. You can also launch their own buying information for users to buy. Shopping website of this type in China shows like buying navigation network, "800 groups".

\section{CurRent Status AND PRoblems of Buying WEBSITE}

\section{A. The development status of the buying website}

Since March 2010, China's first group buying website "For beauties" has been on-line. In just six months, China emerged nearly a thousand buying website. According to statistics, by the end of March 2011, the number of China's domestic buying website has soared to more than 3000 , and the number of people on buying website has reached 200 million [1]. One hand this buying mode is to meet the needs of the users of service and products, and to fill gaps in the market. The price is below the market price. On the other hand, it helps to reduce the merchant's cost of sales. It brings small profits but quick turnover, which is conducive to the return of funds. It is foreseeable that the network buying will become a normal shopping and businesses marketing channels of Internet users.

Buying website rises rapidly in China, which has formed "a war among thousands of website". Various types of buying website outbreak like mushroom. According to statistics, there are 11 new buying websites in China on average every day. Buying mode has a hot development, but buying websites are so different, like good and bad. Smallscale buying websites have been closed down, and the interests of consumers cannot be maintained. The buying mode in China falls into an increasingly embarrassing situation, and the development is increasingly deformed.

\section{B. The problems of buying website}

When group-buying industry is developing rapidly, the problems on the network become more and more serious. These problems are mainly reflected in the following aspects:

1) Lack of a complete credit evaluation system: As online shopping is built on a virtual network platform, anonymity and information asymmetry make online shopping credit problems especially greatly suppress the enthusiasm of consumers buying online, limit the scale of enterprise network transactions, and hinder the whole online shopping's sound development in the market. In 2010, the volume of complaints of group buying in China is 2090. The online purchases integrity becomes widespread, which concerns consumers and businesses. Small and medium buying website often invest a lot of resources in terms of technology platform, businesses discuss, but ignored the core elements of e-commerce - the input of the credit system. So the fraud price, false propaganda, and forcing consumers to do the secondary buying all have occurred. The credit evaluation system of existing buying website is simple and crude. Reference information cannot be provided for other consumers. Although the major network advertised "shopping guarantee" and "risk-free ", as many as thousands of websites still make this industry be mixed. It is the lack of a complete credit evaluation system, which becomes the biggest obstacle in the development of online shopping in China.

2) Low barriers to entry, poor audit mechanism: Buying website is the intermediary of sellers and consumers, which plays a very important role. The audit mechanism of buying website is not perfect, which has a low barrier to entry. They just need a server, several salesmen, technical staff, and funding to set up a buying website. Thousands of buying websites are created in the e-commerce market, but the uneven level of consumer fraud phenomenon frequently happens. Some bad buying websites, pre-publish false information on the site, deceiving consumers to participate. The products and promotion information are inconsistent or make false information. Even defraud buying websites suddenly disappeared. Some buying websites greatly promoted, stimulating consumption and issuing false number of the people buying. One staff who does background technology in a buying website says, it is understood that many buying websites almost always change the number of buyers. Sometimes only dozens of people are involved in the purchase, but they directly put the number of people buying as a few thousand. So businesses and consumers are in substantial losses.

3) After-sales service can't be guaranteed, and it is difficult for consumer to get rights: Group buying attract a lot of consumers by its convenience and affordance, but the businesses involved in the buying cannot guarantee the aftersales service. For example, there is no shopping invoice. It is difficult to refund. Poor product quality and service are also buying traps. Additionally, since the buying website with merchants are unknown of powers and responsibilities, and the shirking of responsibility, consumer rights are difficult to achieve. When the consumer's interests are hurt, they couldn't find a specialized agency to complain. They can just go to the local consumer association to complain. From the business sector, the high cost of rights leads consumers to give up protecting their legitimate rights and interests.

4) Lack of regulation of the industry, and the relevant laws and regulations are not sound: Group buying industry is not standardized. In addition, the virtual and uncontrollable network platform increased the difficulty of industry regulation. Buying behavior involves a wide range, including the buying website, merchants, consumers, logistics, financial institutions and other individuals involved. 
There are no laws and regulations concerning all. In the event of consumer disputes, they have no legal interpretation of the law, which will cause a lot of inconvenience and differences.

5) Audit of business identity certification is not strict, which causes serious fraud: Website does not audit the identity of the merchant strictly, and the merchants are varying on levels of integrity, so in order to achieve low-cost, to ensure the cost, they will choose illegal means. After consuming, consumers can't get commitment to product quality from some businesses, receiving the products which are quite different from the introduction of the website. And some businesses even counterfeit brand-name products, selling the poor instead of the good. Some businesses escaped fled under a single delivery, bringing huge losses to consumers and buying website. Merchant credit is still a guarantee of success in trading.

6) Single business model, unattractive to consumers: The e-commerce market in China has a large number of buying website. Most of them are imitators of the buying website in United States, Groupon. Buying website model is simple, and can be copied with strong mutual high similarity, which is lack of competitiveness. The buying website is facing reshuffle of the industry. Buying website is attractive to consumers, not just due to the website's single solution model, ignoring the needs of individual consumers, but also the following two reasons. One hand, consumer groups select the buying objective as to low price. They are sensitive to price, with spending time left, who are loyal to buying website. On the other hand, buying website information is clutter, and businesses provide goods or services of varying quality, so consumers are not satisfied with shopping, who will not choose to shop on the site. Online shopping websites and businesses are difficult to have a "repeat".

\section{COUNTERMEASURES}

\section{A. The establishment of credit evaluation system, strengthen the buy credit system}

IResearch survey showed that $64.2 \%$ of the public and $71.1 \%$ of the enterprise network transactions would view the seller's credit rating [4]. Group buying mainly focuses on the integrity of the businesses. We should establish Buying Online Merchant Services Credit Evaluation System. Under the supervision of the level of merchant services on consumption, credit evaluation results generated for other consumers to provide reference information, we can ensure that consumers enjoy low-cost and high-quality goods and services, but also can stimulate the merchant credit management, so as to achieve win-win situation.

Large buying website should try to provide different types of evaluation and sharing elements, enhancing consumer trust. By category of goods, for example the establishment of credit evaluation system, we shall encourage consumers to evaluate the businesses, and these evaluations open to the community and micro blogging channels.

\section{B. Strengthen the merchant authentication, and allow high-quality businesses to enter}

By group buying network platform, integrity businesses is not only the promotion of the own products and cost savings, and solve the purpose of the inventory, they can also make buying website accumulation of popularity. Good reputation will also provide consumers with affordable products, which can serve all. If the merchant does not honor the commitment to product quality, and even escaped from the buying website, consumers will suffer huge losses. Therefore, the major buying website should strictly review the merchant identifiable information, such as bank certification, address, authentication, multi-faceted authentication system. It is needed to be assembled by all forces, and formed by the government, financial institutions, intermediaries, credit institutions and individuals' credit, consisting of integrated multi-level authentication system for merchants, and the Authentication and credit certification services. In addition, the website has to increase the strength in the selection of merchants, assessing its operational capabilities and responsibilities of emergency. We can use the deposit system to ensure quality of service, even consider some unscrupulous businessmen blacklisted, and call on the entire group buying industry to block them.

\section{Enhance the industry norms of group buying, establish and improve relevant laws and regulations}

In order to ensure long-term management and more standardized regulation, the industry of group buying need to actively establish industry associations, develop the system of relevant industry associations, and make self-monitoring. The major buying website should develop a detailed service assurance rules enacted to establish customer feedback complaint mechanism, so as to ensure buying quality. In addition to industry self-regulation, national authorities and relevant departments should study the introduction of relevant laws and regulations to improve e-commerce buying, develop the specification of buying website operators behavior of supporting regulatory measures, and be equipped with the appropriate specialized law enforcement forces to protect the purposes of buying [8]. Laws should be made to provide legal protection for the consumer when the consumer disputes.

\section{The establishment of after-sale protection mechanism to ensure the quality of shopping throughout}

Either physical goods or intangible services, good aftersales service support is undoubtedly essential to buying website, which can ensure the consumer damages and compensation. To ensure the quality of the whole buying, buying website must create the consumer sale protection mechanism. Some buying websites try to launch the new model of "co-operation with the Consumers Association to establish million consumer Margin", "strategic cooperation with insurance", "buying-consumption", and "Recruit buying experience staff to evaluate group buying". If the consumer failed to timely consume when shopping, consumer got fake products, the goods received are damaged, or consumers need to refund, the website should be smooth retreat 
reparations mechanism. Buying website can open complaints plate, and set up a customer service center on consumer complaints opinions, dealing with in detail. And the timely results releasing should be clear of responsibility. When encountering consumer disputes, buying website and the merchant should make clear of the responsibility. If it is the problem of product quality and the evidence is conclusive, the website should compensate firstly, and then the buy site claims to the sellers. Because the buying website published false information, consumer rights have been infringed, we should increase the punishment of the website. For major disputes, they should be timely reflected to the local business sector. Buying website should provide consumers with the perfect after-sale protection mechanism, which must increase the trust of consumers buying.

\section{E. The implementation of differentiated business strategy, providing personalized products and services}

Group buying website is based on website characteristics, consumer groups, positioning the business strategy of differentiation, vertical refinement, professional development, such as the micro-transition from "For beauties" to "superior product", which is positioned as a high-quality fashionable cosmetics group buying website, providing genuine value makeup, skin care, beauty products. "Where to go" provides with Hotels Group Buying and tourism buying. We should make clear of buying website's market positioning, find out core competencies, and pay attention to the needs of the consumer group, in order to attract consumers and consumer loyalty.

\section{$F$. Regulate the access to group buying website, strengthen website credit qualification}

Group buying website has a low threshold, so the establishment and closing off are very common. In order to prevent the sudden disappearance of the website, which brings huge losses to sellers and buyers, we need to regulate the access to group buying website, and strengthen credit certification of the website. First, we should actively promote the registration system of the group buying website. Group buying website must require large-scale industrial and commercial registration. The smaller websites should be required to have a business online filing. At present, people in China implement Internet Information Services by the ICP record and ICP license system. In particular, if they apply for one of the conditions of the ICP license, the operator of the registered capital of 100 million or more requires them, which is equal to a domestic company's establishing in accordance with the law. This provision illustrates operators of group buying website must be independent operating entity, but not an individual. Followed by the relevant departments of the credit rating of the group buying website certification and audit record, credit certification will change the current situation of domestic group buying. Ministry of Commerce launched the integrity of the qualification and classification standards, and the Internet Society of China officially released the 2011 results of the first batch of Internet credit rating industry. These specifications promulgation of the regulations will be beneficial to buying orderly development of the industry, and the integrity of the qualified certification help users choose group buying website, thereby reducing the damage of the interests of the user. And the establishment of third-party oversight mechanism is a safeguard for business interests.

\section{SUMMARY}

Group buying website in China is developing rapidly, which has brought a series of credit problems, such as inadequate laws and regulations, unguaranteed after-sales service, the flawed credit rating, which posed a challenge to the development of group buying industry. Therefore, we proposed strategy to solve credit problems of group buying website, so as to strengthen the construction of website credit to ensure the sound development of the group buying website.

\section{REFERENCES}

[1] "Buying Online survey report," Electronic Commerce Research Center

[2] X. Y. Zhou, Y. P. Wu, "E-commerce model of Buying Online," Science and Technology, June 2010.

[3] N. Xu, J. H. Wang, P. F. Zhang, K. Liu, "Investigation and Research on the era of e-commerce of network buying," Ecommerce, 2011, vol. 6 , pp. $55-57$

[4] Z. P. Qing, "Buying Online Merchant credit evaluation study under C2B mode," Yanshan University, Dec. 2010

[5] Z. S. Li, "Network buying drawbacks and Countermeasures," Ecommerce, pp. 196-197

[6] H. Bi, "China's online group-buying Situation and Development Countermeasures," Modern economy, pp. 86-87

[7] X. Y. Zhang, P. J. Liao, "Problems and Countermeasures of the development of the Chinese group buying website," Observation, 2011, vol. 6. pp. 24-25

[8] B. B. Chen, "Development strategy of group buying website in the era of post-group buying," Business economy, 2011, vol. 3, pp. 24-27. 